\title{
Influence of Head Teacher Management of Preschool Programs and Learning Achievement in Mombasa County, Kenya
}

\author{
Ganira K. Lilian, Paul A. Odundo, Muriithi Z. W. \\ Department of Educational Communication and Technology, School of Education, University of Nairobi, Nairobi, Kenya \\ Email address: \\ kgaira@yahoo.com (Ganira K. L.), odundopaul@yahoo.com (Paul A. O.), zelipahmuriithi2@gmail.com (Muriithi Z.W)
}

\section{To cite this article:}

Ganira K. Lilian, Paul A. Odundo, Muriithi Z. W. Influence of Head Teacher Management of Preschool Programs and Learning Achievement in Mombasa County, Kenya. Education Journal. Vol. 5, No. 5, 2016, pp. 81-91. doi: 10.11648/j.edu.20160505.11

Received: February 15, 2016; Accepted: June 15, 2016; Published: August 17, 2016

\begin{abstract}
Management in education is the planning, resourcing, controlling, organizing, leading and evaluating educational institutions and programs. Organizational management is a key factor that influences teaching and learning in schools Chitiavi, (2002). Among key variables that school management influences significantly is children's ability to learn and perform well which is a key determinant of learning achievement. Therefore head teachers are expected to possess relevant managerial skills to run schools. Physical facilities and human resources are paramount to achieve high learning achievements in schools. The purpose of this study was to establish impact of pre-school management on children's learning achievement in Mombasa County, Kenya. Samples surveyed were public, private, faith-based and community pre-schools. The assumption was that managers focussed on four levels of management namely; human resource management, curriculum management, financial management and physical resources management. The study adapted descriptive survey design where samples included 11 preschools, 11 head teaches and 11 teachers 11 Parents and 106 preschool children. Instruments of this study were questionnaires and interviews schedules. Findings revealed that majority of pre-school teachers are paid very low salary between KShs 5001 and 9001 per month which is below stipulated minimum wage. Despite low salary, 54.5\% of teachers prepared for teaching adequately. About $45.5 \%$ of all pre-schools have adequate playing and instructional resources. Private schools had an overwhelming $80 \%$ of parents who showed direct interest in childrens' learning. Public primary headteachers manage preschools attached to their schools and therefore have no direct impact on pre-school progress. The study recommends that public pre-schools should be managed separately from primary schools and the pre-school head teacher should possess essential managerial skills to improve school efficiency and learning achievement for children.
\end{abstract}

Keywords: Learning Achievement, Human Resource Management, Professional Development, Curriculum Implementation, Parental Involvement

\section{Introduction}

Education management is the achievement of objectives through people in the process that involves planning, resourcing, controlling, organizing, leading and evaluating educational programs. Headteachers as managers, teachers and parents should be instrumental in providing vision, and resources to support professional development, curriculum implementation, school improvement and learning achievement in preschool education. A positive school climate, coupled with a vision of academic success, and cultivating leadership in staff, parents and community partnership are vital for supporting learning achievement. In this regard, schools that foster trust among headteachers, teachers and parents are more likely to witness learning achievement than schools that do little to foster trust, Tilbury, \& Ryan, (2011). Thus, Gakuru, Riak, Ogula, Mugo and Njenga (1987) highlighted that organizational management of pre-schools influences success in teaching and learning. Therefore effective management of preschool education is a prime contributory factor in academic and learning achievement. The government of Kenya has a variety of preschool programs including pre-unit, nursery, kindergarten, day-care, Montessori, madrasa and creche's among others. 
Besides public pre-schools, there is a significant private, faith-based and community-based preschool system. According to Mutero (2001) variation in pre-school programs and institutions has produced huge disparities in school resources, tuition fees and management styles that affect learning achievement among children. As a result the government faces challenges in relation to registration of preschools, supervision, quality control, coordination, standards keeping and management of the entire sub-sector.

Although Education Act confers extensive powers on the minister of education over management and regulation of education in Kenya, the day to day running of affairs of school falls directly on the head teacher. Head teachers of primary schools are also in-charge of running pre-schools attached to their schools. Non-public pre-schools, are managed by owners/proprietors and sponsors. Thus Weihrich and Koontz (1993), pointed out that an effective school manager should have ability to coordinate all functions of a manager including human, physical and financial resources of a school. However, Wanderi, 2008 and Ogembo, (2005) revealed that many head teachers lack pre-requisite management skills whose consequence is poor management of resources which in turn affect teaching and learning as well as children's performance. In this regard, pre-school Service Standard Guidelines for Kenya (2006), stressed that parents should be incorporated in management committees, with responsibilities of identifying needs of pre-school services within communities and developing usable strategies for meeting the same; for example, mobilizing parents and local communities to initiate and sustain schools; mobilizing parents and local communities to support programmes; managing the program; recruiting qualified pre-school teachers and other personnel and ensuring that they are paid. Consequently a significant proportion of pre-schools in Kenya are not run by personnel with pre-requisite knowledge in management. Based on this background, this study analysed impact of preschool management practices on learning achievement in Mombasa County in Kenya.

\subsection{Human Resource, Management and Learning Achievement}

Teacher motivation especially remuneration, and changing the way teachers are paid including raising pay levels is the most effective way of responding to school improvement challenges. In support of this view, Springer, Matthew \& John (2012) opined that incentivized teacher will work harder and produce better results. However, studies that estimate relation between learning achievement and teacher remuneration have produced little consistent evident that students perform better when teachers have high salaries, National Research Council and National Academy of Education (2010). Besides, if teachers do not increase learning achievement then motivation may have negative impact on achievement. Despite contradictory research findings that link remuneration to learner achievement, there has been a growing enthusiasm among educational reforms and policy makers around the world to link learning achievement and teacher motivation, Bettinger, (2010). For instance in 2010, U.S department of education, states applying for funds for teacher incentive are evaluated on effectiveness by linking teacher evaluation to student growth, and making decisions about student achievement, Archibald, Coggshall, Croft, \& Goe, (2011). In addition studies conducted in 25 countries in Europe concluded that teacher quality is the most important factor in an educational organization, and the second important factor that influence student achievement Bruce Esmonde, Ross, Dookie \& Beatty. (2010). Conversely, data from field experiments in Kenya and India yield effects sizes of approximately 0.02 standard deviations in Mathematics and reading when teachers earned 2 percentage and 3 percentage of their yearly salaries respectively, Glewwe, Nauman, \& Kremer, (2010). Further still, analysis on academic achievement in Mathematics in Baringo County, Mbugua, (2012), found out that performance in Mathematics is below average and attributed this to inadequate incentives. Thus financial motivation for learning achievement may have a positive impact by motivating teachers to increase effort in curriculum efficiency, assessment and satisfactory evaluation.

\subsection{Professional Development, Management and Learning Achievement}

Professional development is a continuing and rigorous approach to improving teacher's and manager's effectiveness in raising learner achievement. For managers and teachers to be effective in school leadership, they should constantly expand knowledge and skills to implement best educational practices. In this regard, Githae et al., (2015), opined that since professional development is a key indicator to teacher's potential towards solving problems, preschool teachers require financing for capacity building through refresher courses that improve skills for curriculum implementation. Hence effective professional development should influence team building, quality instruction, leadership and mentoring skills, curriculum development and efficacy. In support of this observation, Duflo, Dupas, \& Kremer, (2011) found out that children assigned to teachers with effective professional development have better grades, high test scores, better self esteem, and show higher aspiration and motivation towards school since curriculum interpretation is mediated by teacher's knowledge and practice in the classroom. However, Yoon, Duncan, Scarloss \& Shapley (2007), disclosed that few teachers receive intensive, sustained and content focused professional development. Similarly, if a teacher fails to apply new ideas from professional development to class instruction then learner achievement is likely to be thwarted. In addition, Voss, Kunter, \& Baumert, (2011), argued that professional development enhances teacher knowledge and skills, efficiency in class instruction which in turn translates into improved results and gains in learner achievement. In this regard, professional development should be intensive, content focused, coherent, well defined and strongly implemented. If gains from professional development are effectively utilized then preschool are likely to experience 
improved school performance, quality instruction and implementation, and new initiatives for learning achievement.

\subsection{Curriculum Implementation, Management and Learning Achievement}

Curriculum implementation entails putting into practice officially prescribed courses of study, syllabuses and subjects. Consequently, teachers with a sense of efficacy tend to show high levels of planning and organization, are open to new ideas and exhibit enthusiasm for teaching, TschanenMoran, McMaster, (2009). Conversely, if a teacher fails to implement curriculum effectively then instruction suffers which in turn impacts negatively on learning achievement. In Kenya, for effective curriculum delivery to be realized Quality Assurance and Standards Officers (QASO) are expected to visit schools regularly, organise seminars and inservice course for teachers and provide advisory service on how best to improve instruction. In addition Akyeampong, Lussier, Pryor \& Westbrook (2013), emphasized that headteachers should manage the process of teaching and learning within the school in accordance with curriculum documents and policies. Given that adequate facilities such as classrooms, libraries, halls and playing fields are prerequisite for successful curriculum implementation, Hopkins, \& Higham, (2007), put forward that Preschools need adequate classrooms to alleviate overcrowding since success of curriculum implementation is dependent on provision of necessary resources and facilities to ensure enthusiasm of teachers and children

\subsection{Parental Involvement, Management, and Learning Achievement}

Effective parental involvement occurs when an appropriate partnership exists between schools and families. Children with parents who are concerned with school tend to have less behavioural problems; experiences enhanced academic performance and are likely to complete schooling than those whose parents are not involved. In a study on effects of parental involvement on achievement for a sample of 3-7 year olds in Washington DC, Hill, \& Tyson, (2009), revealed that parental involvement is a major factor for success. The study used standardized assessment tests to measure achievement. As a result children's positive attitude about schooling improved, self esteem, self concept as well as self-discipline were enhanced. To this effect, involvement in the school and parental monitoring confirmed positive effects on moderating inconsistency and achievement levels. In another study on parental choice and learner achievement in primary schools in Kenya Oyier et. al., (2015), confirmed that one technique in which parents are involved in children's education is through choosing schools that are environmentally safe since safety embodies educational priority in decision making. Consequently a safe and secure environment facilitates and fosters quality teaching and learning in educational institutions. In this regard, Vaden-Kierna., \& McManus, (2005), emphasized that teachers of children with highly involved parents tend to give greater attention to the children and are more likely to identify at earlier stages problems that might hinder learning. Therefore, if children are to maximise potential from school then parental participation is vital in providing training skills financial support and advice for learner achievement. In addition, effective involvement allows parents to monitor school and class activities and coordinates efforts with teachers to encourage acceptable behaviour and ensure that the child completes school work. For this reason, parental participation includes: Participation in school event, taking part in school management and governance, visiting the school to discuss issues and concerns, and contacting the school to learn about rules, procedures, curriculum and assessment.

\section{Statement of the Problem}

Overtime, pre-school sub-sector has greatly expanded for both public and non-public education with a huge privately provided pre-school service, particularly in large urban centres throughout the republic. Observation as well as research reveals that much of the non-public pre-school subsector has become commercial ventures with all sorts of entrepreneurs investing in the sub-sector, Wanderi, 2008 and Ogembo, (2005). Further still, Private business people, faithbased organizations, communities and main stream public primary schools offer pre-school services. However, government regulatory and monitoring authorizations are inadequate. Hence children and parents as well as other stakeholders are exposed to unscrupulous business with little concern for quality education, Cheboi (2010). According to Rutter, Maugham, Mortimer and Smith (1997), \& Republic of Kenya (2005), there is a positive relationship between learners' performance and head teachers' managerial skills given that interaction between physical facilities and human resources promote learning achievements. However, appointments of head teachers are based on academic and professional qualifications which do not necessarily signify a qualification in school managerial skills. Furthermore Mbugua, (2012), found out that many head teachers have not undertaken managerial courses and therefore are inadequate in managing preschools effectively. Based on these observations, the study examined impact of management practices in preschools on children's learning achievement in Mombasa County in Kenya.

\section{Purpose and Objectives of the Study}

The purpose of this study was to examine influence of preschool management practices on learning achievement. The objective was to establish the relationship between management practices and learning achievement. Study finding will contribute to advancement of knowledge on appropriate management of preschool education. The study will also benefit ministry of education in formulating policies that guide effective management of preschools. 


\section{Theoretical Framework}

The study utilized school-based management (SBM) theory, stipulated by Leung, (2003). School-based management is the decentralization of authority from central government to school level, Caldwell, (2002) where transfer of responsibility and decision making is handed over to principles, teachers, and community members. However, school level actors have to conform within set of policies determined by the central government. In this regard all managers of schools are empowered to strengthen professional motivation, thereby enhancing sense of ownership of the school by involving local community in decision making. Parents may monitor school's performance for example in test scores, teacher and student attendance, raise funds, and create endowment for the school to appoint, suspend, dismiss or remove teachers and ensure that teachers' salaries are paid regularly. In applying SBM, UNESCO and Organization for Economic Cooperation and Development (OECD), (2005), noted that devolving responsibilities to principles, teachers and the local community is for the objective of raising performance levels of schools. Thus effective management of preschools through appropriate human resource management, curriculum management, financial management and physical resource management is likely to increase client satisfaction and improve learning achievement. Additionally if headteachers are given autonomy over use of inputs, then preschool are likely to experience sustained learner achievement, improved motivation towards School and enhanced community support.

\section{Conceptual Framework}

School succeed on effective management and participation of head teachers, teachers and local communities. In a bid to ensure effective management, schools require physical facilities and financial resources for building capacity of education systems and to deliver quality and relevant curriculum to all children. Hence, head teachers ensure that effective organization, utilization, supervision and management of curriculum activities and public accountability in the use of resources are geared toward learning achievement. The teaching learning process is supervised by the head teacher through instructional modelling, mentoring, monitoring, evaluation, record keeping and feedback. This provides the basis for determining level of progress made in implementation of curriculum for effective transformation of preschool children. The teacher is responsible for curriculum planning, delivery, learner's assessment, record keeping and motivation of children for active participation in learning activities. Participation of parents in school management ensures quality education by providing infrastructure, learning resources and financial support. It is envisaged that effective management should enhance academic performance, motivation towards learning as well as sustained learning outcomes and quality education for preschool children.

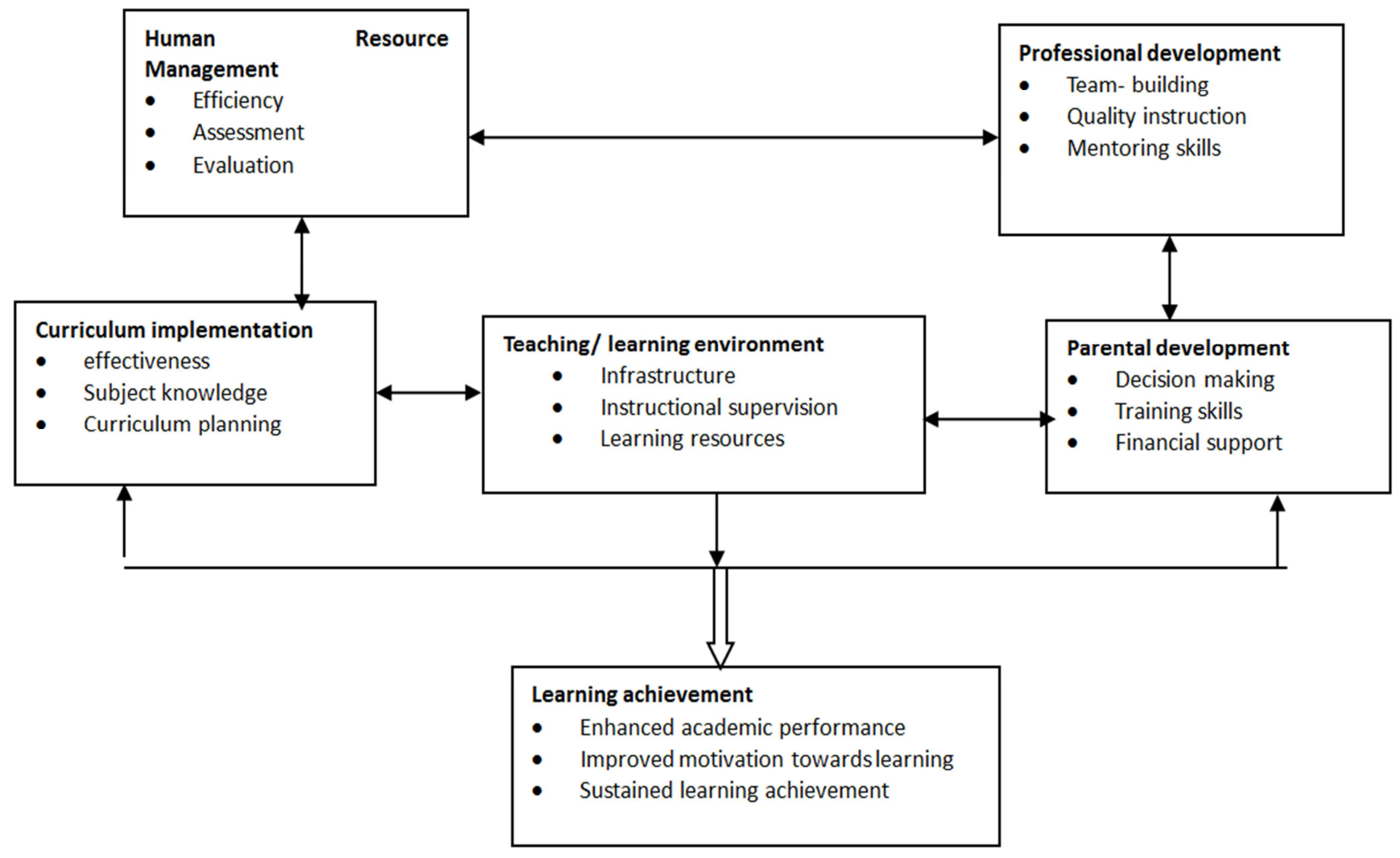

Figure 1. Conceptual framework. 


\section{Methodology}

The study adapted descriptive survey design with samples including 11 pre-schools, 11 head teaches and 11 teachers. Additionally 11 Parents responded to interviews that sought to identify views of the community. A total of 160 children were involved in the study. Questionnaires and interview schedules were used for data collection. There were different categories of pre-schools comprising of public (GoK), private (purely individual), faith-based (Muslim and Christian) and nonformal schools (community schools). A multi-stage sampling technique was used. The schools were then stratified into different characteristics, that is, public, private, community and faith-based schools. Stratified sampling ensured that certain subgroups in the population are represented in the sample in proportion to their number in population Kombo and Tromp,
(2006). Random sampling was then done on each stratum to identify 11 pre-schools. Also in the population was Municipal Education Officer (MEO) in charge of all the pre-schools in the county and zone quality assurance and standards officer (ZQASO).

\section{Findings and Discussions}

\subsection{Human Resource Management (Teacher Motivation)}

Staff motivation is one of the human resource management aspects in the management of an organization. Teachers and other staff require adequate remuneration which reflects the work that they do. There was a marked difference in remuneration levels among different types of pre-schools. The findings are as shown in Table 1.

Table 1. Remuneration for head teachers.

\begin{tabular}{|c|c|c|c|c|c|c|}
\hline Salary per month (Khs) & Public schools & Private schools & Community schools & Faith-based schools & Total & $\%$ \\
\hline $2000-5000$ & 0 & 2 & 1 & 1 & 3 & 27.3 \\
\hline $5001-9000$ & 2 & 1 & 1 & 0 & 5 & 45.5 \\
\hline Over 9000 & 0 & 2 & 0 & 1 & 3 & 27.3 \\
\hline TOTAL & 2 & 5 & 2 & 2 & 11 & 100 \\
\hline
\end{tabular}

Survey data 2014

From the table 1, out of the 11 ECD head teachers $27.3 \%$ were paid below 5000 per month while the same proportion of teachers earned more than 9000 per month. Majority of head teacher received a salary of between 5001-9000 per month. In the categories of schools, public schools head teachers were paid a salary of 5001-9000 per month while $40 \%$ of private school paid a salary of more than 9000 per month. This suggests that teachers in private schools are well remunerated than those from the public, Community and faith-based schools. Generally salary level stipulated on the table 1 implies that preschool managers are poorly paid. Currently the minimum wage in Kenya is about 10,995 (Republic of Kenya, 2015). It means therefore that preschool managers $(45.5 \%)$ are paid below the minimum wage. Given that remuneration would be a good measure for motivation, it therefore translates to low job satisfaction and low morale for head teachers. In some instances teachers are even paid lower than domestic workers (average Kshs. 10,995). Respondents strongly suggested that preschool teachers should enter main stream employment by the government through Teachers Service Commission. Further they suggested that they should be able to establish a wage bargaining platform by forming trade unions to negotiate for better terms and conditions of service. All the pre -school head teachers are employed on contractual terms and hence are less motivated since they are not certain about their future. According to Springer, Matthew \& John (2012) incentivized teacher will work harder and produce better results while a less motivated teacher exhibits low motivation which may have negative impacts on learner performance.

\subsection{Professional Development and Learner Achievement}

Professional growth is an important variable that influences learning achievement. To this end opportunity for attending seminars, conventions, workshops and in-service programs is important in increasing pedagogical skills for effective teaching. Table 2 shows data on head teacher personal professional growth.

Table 2. Human Resource: Head Teacher Professional Growth (in-service).

\begin{tabular}{|c|c|c|c|c|c|c|}
\hline Duration & Public schools & Private schools & Community schools & Faith-based schools & Total & $\%$ \\
\hline Once per term & 2 & 1 & 1 & 1 & 5 & 45.5 \\
\hline Semi-Annaully & 0 & 3 & 1 & 1 & 5 & 45.5 \\
\hline Annually & 0 & 1 & 0 & 0 & 1 & 10 \\
\hline $\begin{array}{l}\text { TOTAL } \\
\text { Survey } 2014\end{array}$ & 2 & 5 & 2 & 2 & 11 & 100 \\
\hline
\end{tabular}

As part of school management, head teachers are required to motivate teachers by encouraging them to pursue professional growth. One such way is to create opportunities for attending in-service courses, seminars and workshops.
Thus, Voss, Kunter, \& Baumert, (2011), argued that professional development enhances teacher knowledge and skills, efficiency in class instruction which in turn translates into improved results and gains in learner achievement. The 
head teacher as managers in schools, hold pivotal role around which many aspects of the school revolve, and they are in charge of every detail of running of the school, be it academic or administrative. From table 2, 45\% of the head teachers provided opportunities for teachers professional growth once per term and semi-annually. All public schools in this study had their teachers attending in-service courses. Out of a total of 5 teachers in private pre-schools, 3 attended in service courses semi-annually $(60 \%)$. Though public preschool teachers had attended in-service courses, children performed poorly compared to those in private preschools. Public pre-school head teachers as well as other regular teachers were exposed to training opportunities as a result of government policy that required them to improve capacities as professionals. Therefore, education officers were in-charge of training in each county across the country. On the other hand, it was found out private, community and faith-based preschools needed to finance in-service courses for teachers they lacked adequate finances. Since private preschools are profit-driven, the focus is to ensure that children perform well academically. Since, Githae et al., (2015), opined that professional development is a key indicator to teacher's potential towards solving problems, preschool teachers require financing for capacity building through refresher courses that improve skills for curriculum implementation. However, profit motivated organizations and in particular academic institutions consider academic achievement as the most important objective. This position concurs with the finding of this study where learning achievement (performance) is the most crucial aspect of private preschool operations in Kisauni Sub-county of Mombasa County.

\subsection{Curriculum Implementation}

In order to assess impact of school managers in curriculum implementation, this study analysed teachers' preparedness in teaching and in record keeping procedures. The responses are as shown in the table 3.

Table 3. Curriculum (Preparation-schemes, lesson plan, child records).

\begin{tabular}{|c|c|c|c|c|c|c|}
\hline Curriculum & Public schools & Private schools & Community schools & Faith-based schools & Total & $\%$ \\
\hline Excellent & 1 & 3 & 2 & 0 & 6 & 54.5 \\
\hline Very good & 0 & 0 & 0 & 1 & 1 & 9.1 \\
\hline Fair & 0 & 2 & 0 & 0 & 2 & 27.1 \\
\hline Poor & 1 & 0 & 0 & 1 & 1 & 9.1 \\
\hline TOTAL & 2 & 5 & 2 & 2 & 11 & 100 \\
\hline
\end{tabular}

Survey data 2014

From data presented on the table 3, majority of pre-schools teachers $(54.5 \%)$ prepared excellently for teaching as observed from their documents. In this category however, private preschool had a majority of them $(60 \%)$ whose preparation was excellent for teaching in terms of schemes of work, lesson plans and children's' records. This finding suggests that there is adequate supervision in private and community schools. This explains why private schools performed well in end of term examinations than public, community and faith-based preschools. A notable finding was that half of the public preschools $(50 \%)$ were rated poor in terms preparation for teaching and keeping children's records. This finding corroborate with the earlier finding that due to poor remuneration, teachers have very low motivation to undertake extra tasks like record keeping, marking and remedial work. Therefore Akyeampong, Lussier, Pryor, Westbrook (2013), emphasized that headteachers should manage the process of teaching and learning within the school in accordance with curriculum documents and policies. The head teacher (manager) is the key person to ensure that teachers are prepared adequately and keep up to date documents of children in terms of attendance, absenteeism, sickness as well as performance. The faith based preschool had mixed findings. Some prepared well while others prepared poorly. In addition, this category emphasized faith based doctrines in their teaching.

\subsubsection{Remark on Children's Work}

Another key aspect of head teacher's responsibility was to ensure that teachers provided individualized attention to the children. An important activity for the teacher was to ensure that children's books were marked and necessary corrections and remedial done to increase quality of learning and performance. Table 4 shows rating of different preschools on these aspects.

Table 4. Remark on children's exercise books.

\begin{tabular}{|c|c|c|c|c|c|c|}
\hline Remark on children exercise books & Public schools & Private schools & Community schools & Faith-based schools & Total & $\%$ \\
\hline Good & 0 & 2 & 1 & 1 & 4 & 36.4 \\
\hline Average & 2 & 2 & 1 & 1 & 6 & 54.5 \\
\hline Poor & 0 & 1 & 0 & 0 & 1 & 1.9 \\
\hline TOTAL & 2 & 5 & 2 & 2 & 11 & 100 \\
\hline
\end{tabular}

Survey data 2014

The activity of remarking was assumed to include marking exercises, children's activities and carrying out necessary corrections and remedial for children. Teachers were rated as good, average or poor across the preschools. About $54.5 \%$ of the schools were rated average while $36.4 \%$ were rated good. Only a small proportion was rated poor at $1.9 \%$. In terms of 
individual categories of preschools, private preschools were observed to have attained the level of good $(40 \%)$. It is on this basis that head teacher act as managers whose responsibility is to manage its core resource. The teacher also ensured that teachers remained focused on children's progress as well as individual differences so as to ensure smooth learning across classes. Since children's cognitive and psychomotor perspectives are key to development of learning, feedback and remedial were important in ensuring that children's learning achievement improved.

\subsubsection{Financial Management - Audit of Financial Records}

No organization, including schools can achieve its goals without managing financial resources as well as auditing accounts to control the whole financial process. Since financial resources are often reflected in schools' budgets, it was evident that all pre-schools faced financial constraints. In order to assess financial management, this study collected information on availability of financial records and the level of update as reflected on table 5 .

Table 5. Financial management -Audit of Financial records.

\begin{tabular}{|c|c|c|c|c|c|c|}
\hline Financial Records auditing & Public schools & Private schools & Community schools & Faith-based schools & Total & $\%$ \\
\hline DSA & 1 & 0 & 1 & 0 & 2 & 18.2 \\
\hline Internal audit & 0 & 3 & 0 & 0 & 3 & 27.3 \\
\hline Part-time audit & 1 & 0 & & 1 & 3 & 27.3 \\
\hline No audit & 0 & 2 & 0 & 1 & 3 & 27.3 \\
\hline TOTAL & 2 & 5 & 2 & 2 & 11 & 100 \\
\hline
\end{tabular}

Survey data 2014

From table 5, private and faith based public pre-schools centres did not involve district audit office (DSA) in financial and budgeting processes. On the same vein, public, faithbased and community schools did not engage part-time audit expert in keeping records for financial management. On aggregate large number of pre-schools $(27.3 \%)$ did not audit finances at all yet in public primary schools, School Management Committees are mandated to manage, audit and regulate expenditure by the head teachers in order to ensure that all revenues are utilized to purposes specified. It was assumed from that head teachers were reluctant to provide figures that reflected true financial transactions of their schools. In addition, auditing by the district office (DSA) was done in an unclear manner an indication that they were probably unscrupulous and corrupt. The head teacher however indicated that a large proportion of finances were used to pay salaries and wages for the staff. There was however no direct relationship between financial management practice and children's learning achievement for all the pre-schools. This implies that members of the school managers are ill equipped and did not have pre-requisite financial management skills required for learning achievement. Rather it was parents who purchased instructional resources and paid school fees to meet salaries requirement as well as other expenses. The private, faithbased and community schools were not regularly audited by the government through DSA office. This therefore provided these institutions with opportunities to manage finances the way the perceived would meet their operational needs. This contravened Education Act which states that Board of Governors were mandated to audit and regulate expenditure by the school administration to ensure that all income received by the school is applied to the promotion learning by pupils.

\subsubsection{Financial Management (Training) Skills}

The school manager was expected to be in full charge of the pre-school's financial resources. The head teacher was expected to possess basic skill in book-keeping and financial control. However, appointment into head teacher position in all schools was not based on financial management skills but on academic or professional qualifications. This study intended to establish if the head teachers attended any financial management seminars or workshops to improve on financial management skills. The results of are shown in table below 6 .

Table 6. Financial management training (Skills).

\begin{tabular}{|c|c|c|c|c|c|c|}
\hline Financial management training (skills) & Public schools & Private schools & Community schools & Faith-based schools & Total & $\%$ \\
\hline Yes & 2 & 2 & 2 & 2 & 8 & 72.7 \\
\hline No & 0 & 3 & 0 & 0 & 3 & 27.3 \\
\hline TOTAL & 2 & 5 & 2 & 2 & 11 & 100 \\
\hline
\end{tabular}

Survey data 2014

With reference to the table 6, (8) $72 \%$ of head teachers indicated that they had attended a refresher course of financial management. All the head teachers from public sponsored schools, the Community and Faith Based Schools had attended such courses. In the private schools, $60 \%(\mathrm{~N}=3)$ had attended course on financial management while $40 \%$ $(\mathrm{N}=2)$ had not. This could be due to the reason that private schools avoided close scrutiny and auditing to evade income tax department as well as other financial statutory mandates by the government. The schools basically existed for commercial purposes and were managed by the owners or their protégés. These set of managers did not therefore consider management and financial skills as necessary in management of pre-schools. Though there was a large 
number of pre-school heads who agreed that they had skills of managing finances, there was no clear linkage with children's performance. However, management as perceived from a functional and structuralist perspective is a process of planning, organising, leading, and controlling to ensure effectiveness within an organisation. The head teacher thus acted as a manager who was supposed to be active in the field of management of resources and management of people and hence required skills to carry out managerial tasks of the pre-school. It was therefore clear that there was need to ensure that school managers obtained financial management skills.

Table 7. Class size (Space for learning).

\begin{tabular}{lllllll}
\hline Class size for learning & Public schools & Private schools & Community schools & Faith-based schools & Total & \% \\
\hline Strongly agree & 0 & 4 & 1 & 0 & 5 & 45.5 \\
Agree & 0 & 1 & 1 & 1 & 3 & 27.3 \\
Disagree & 0 & 0 & 0 & 1 & 1 & 9.1 \\
Strongly disagree & 2 & 0 & 0 & 0 & 2 & 18.1 \\
TOTAL & 2 & 5 & 2 & 2 & 11 & 100 \\
\hline
\end{tabular}

Survey data 2014

\subsubsection{Class Size}

Development of physical facilities/infrastructure for a preschool is vital for enabling children enough space for learning activities. Such space subsequently enables children to learn better and effectively. The respondents were asked whether they agreed or disagreed as to whether classroom size was adequate for learning purposes.

Findings from table 7 shows $45.5 \%$ of the respondents strongly agreed that classrooms were adequate in size. Majority of the private schools $(80 \%)$ strongly indicated they had adequate space in their classroom for children to learn and carry out manipulative activities. This could be explained by the fact that private schools were largely profit motivated and strived to create conducive environment to attract more clients. Managers in private schools might also have realised that small classes were easier to manage and helped boost performance of children. Hence teachers who worked with fewer children are able to mark and correct children's activities and provide feedback more frequently. Therefore they were also able to cover the curriculum in much depth than those in larger classes. The Classrooms space was not inadequate in all public schools due to overenrolment. Note that despite the fact that primary education is free of tuition, pre-school is not free. A significant number of parents took their children to public pre-schools to access Free Primary Education (Republic of Kenya, 2005). Classrooms in Faith based schools have enough space and class sizes. Such schools subscribed to parents' religion/faith and hence higher probability of sending children to faith based schools.

\subsubsection{Field and Classroom Resources}

Play materials are important in influencing learning achievement for pre-school children. Research has shown that there is a positive correlation between play materials and learning achievement. The respondents were asked whether resources were adequate. The results are shown on the table 8 .

Table 8. Resources (play and learning materials).

\begin{tabular}{|c|c|c|c|c|c|c|}
\hline Availability of playing resources & Public schools & Private schools & Community schools & Faith-based schools & Total & $\%$ \\
\hline Strongly agree & 0 & 4 & 1 & 0 & 5 & 45.5 \\
\hline Agree & 0 & 0 & 1 & 1 & 2 & 18.1 \\
\hline Disagree & 0 & 0 & 0 & 1 & 1 & 9.1 \\
\hline Strongly disagree & 2 & 1 & 0 & 0 & 3 & 27.3 \\
\hline TOTAL & 2 & 5 & 2 & 2 & 11 & 100 \\
\hline
\end{tabular}

Survey data 2014

Findings from table 8 revealed that $80 \%$ of private schools agreed that they had adequate playing materials. On the other hand public schools had least of the playing materials children needed for learning. The results of both faith-based and community pre-schools were mixed. Education experts believe that play and learning are important components of children's growth and development. Adopting a physically active lifestyle in early life increases likelihood that children will be active in manipulative skills necessary for creating a good foundation for life. Therefore it was strongly observed that a policy is required for pre-school sub-sector to lay emphasis on play and learning materials in order to improve children's growth and development in a holistic manner.

\subsection{Parental Involvement}

The study established whether there was parental involvement in the management of pre- schools. In circumstances where parental involvement was high, there was tendency and desire to improve quality of learning and hence performance for children. As to which category of school involved parents more or less, the results were as shown on the table 9 . 
Table 9. Parents' involvement in decision making for school management.

\begin{tabular}{|c|c|c|c|c|c|c|}
\hline Parental involvement in school management decisions & Public schools & Private schools & Community schools & Faith-based schools & Total & $\%$ \\
\hline Yes & 0 & 4 & 2 & 2 & 8 & 72.7 \\
\hline No & 2 & 1 & & 0 & 3 & 27.3 \\
\hline TOTAL & 2 & 5 & 2 & 2 & 11 & 100 \\
\hline
\end{tabular}

Survey data 2014

From table 9, majority of the pre-schools of (72.7\%), strongly agreed that parents were involved in decision making. Note however that private pre-school had the highest involvement level of the parents. Given the nature of private schools, it was evident that parents who took children to these pre-schools could afford to pay higher fees and were also keen on children's progress in school. Public pre-school had the least parental involvement particularly with respect to pre-school level. Where parental involvement was high, they contributed in many issues including financial management, hiring of teachers, discipline matters, resource allocation as well as staff welfare. Heads of primary schools are expected to manage pre-schools as they are part of public primary school system and subsequently involve parents in management of the schools.

\section{Conclusions}

On average a pre-school head teachers earned a salary that was below minimum wage of Kshs, 10,995 per month. This was found to be the cause of low morale among heads of schools which may have translated to poor performance. There was a strong suggestion that public pre-school teachers enter main stream employment through the Teacher Service Commission (TSC). Further they observed that they would be able to bargain for their conditions and terms of service as the rest of teaching fraternity by joining existing trade unions or form new ones. Public pre-schools had a higher percentage of teachers attending training opportunities than all other categories of pre-schools. However performance low. There was is an urgent need for private schools, faith-based and community school to ensure that teachers accessed opportunities for professional up grading.

Private preschool had a majority of their teachers $(60 \%)$ who prepared for teaching in terms of schemes of work, lesson plans and pupils records. This suggests that there was good curriculum supervision in the private and community schools. This explains why private schools performed well at their overall than all other pre-schools. A notable finding was that half of public preschools $(50 \%)$ were rated poor in preparation for teaching and keeping pupil's records. There was mixed results for faith-based and community preschools. It was also concluded that head teachers' responsibilities included management of both human and physical resource. Consequently there was need for heads of schools to endeavour to train in financial management skills and competencies. It was also found out that it was head teachers responsibility to ensure successful efficient implementation of curriculum by class teachers. Many of the school did not have accounts audited for purposes of financial control. Therefore a policy is required to mandate schools to succumb to financial auditing processes. In addition head teachers should undergo necessary financial and management training.

Play materials for children are important in influencing learning achievement for pre-school children. Therefore it was recommended that a policy is required for the pre-school sub-sector to lay emphasis on play and learning materials for children's benefit in terms of growth and development. There was a feeling that schools which involved parents and the community in management of schools had prudent managers who focussed on improving quality of education for children. There was therefore a need to involve parent in important school decisions like management of human and physical resources, discipline, teachers hiring/firing as well as academic progress for the children.

\section{Recommendation}

Based on the conclusions discussed in the previous section the study makes the following recommendations:

(i) That the government should effectively implement policy of quality assurance and standards (QAS) specifically for the pre-school sub-sector in Kenya. It was found that some private pre-school had questionable registration documents and committed other malpractices which affect the sub-sector negatively. Therefore the government should formulate policies that enhance quality assurance in all preschools.

(ii) The government is advised to conduct research to establish why there is a large difference in children's learning achievement levels between public and private pre-schools. In addition a case was presented for increased allocation for funding for public preschools across the country.

(iii) The government is advised to consider formalizing employment of pre-school teachers through Teachers Service Commission. Though responsibility of preschool education is a devolved function, it experiences a myriad of problems which should be solved by taking the sub-sector to the national government. This would provide teachers with security of tenure and hence motivation. The government should also come up with guidelines for pre-school teachers' remuneration to protect them from being exploited by unscrupulous employers who overwork them and pay them meagre salaries. 


\section{References}

[1] Archibald, S., Coggshall, J., Croft, A., \& Goe, L. (2011). High-quality professional development for all teachers: Effectively allocating resources. Washington, DC: National Comprehensive Center for Teacher Quality. Retrieved March 19, 2012, from

http://www.tqsource.org/publications/HighQualityProfessional Development.pdf

[2] Akyeampong K, Lussier K, Pryor J, Westbrook J (2013) Improving teaching and learning of basic maths and reading in Africa: Does teacher preparation count? International Journal of Educational Development, 33 (3): 272-282.

[3] Bettinger, Eric. 2010. \Paying to Learn: The E ect of Financial Incentives on Elementary School Test Scores. NBER Working Paper No. 16333

[4] Bruce, C. D., Esmonde, I., Ross, J., Dookie, L. \& Beatty, R. (2010). The effects of sustained classroom-embedded teacher professional learning on teacher efficacy and related student achievement. Teaching and Teacher Education (in press), doi: 10.1016/j. tate.2010.06.011.

[5] Caldwell, B. J. (2002). Autonomy and self management: Concepts and evidence. In Bush, T. \& Bell L. (Eds) The Principals and Practice of Educational Management (pp 2140) London: Paul Chapman publishing.

[6] Cheboi', S. (2010). "Blow to Nursery Public School Plan as Uhuru Fails to Give Cash" Daily Nation, $4^{\text {th }}$ July, 2010, page 17, column 2 .

[7] Duflo, E., Dupas, P., and Kremer, M. (2011). Peer effects, teacher incentives, and the impact of tracking: evidence from a randomized evaluation in Kenya. American Economic Review, 101 (August 2011): 1739-1774.

[8] Gakuru, 0. N., Riak, P. F., Ogula, P. H., Mugo, R., \& Njenga, A. W. (1987). Evaluation of NACECE-DICECE Programme-Part One: Research findings and recommendations. Nairobi, Kenya: Kenya institute of Education.

[9] Githae G. M, Odundo P. A, Mwangi J. (2015) "Influence of Finance in Mainstreaming Support for Orphans and Vulnerable children (OVC) in Nyeri Central District, Kenya." International Journal of Elementary Education,. 2015; 4 (1).

[10] Glewwe, P., Nauman, I., \& Kremer, M. (2010). Teacher incentives. American Economic Jour-nal: Applied Economics, 2, 205-227.

[11] Hill, N. E. \& Tyson, D. F.(2009). Parental involvement in middle school: a meta-analytic assessment of the strategies that promote achievement. Developmental psychology, 49 (3), 740-763.

[12] Hopkins, D \& Higham, R, 2007, System leadership: mapping the landscape. In School Leadership andManagement, 27 (2), $147-66$.

[13] Kombo, D. K. and Tromp, D. L. A. (2006). Proposal and Thesis Writing: An Introduction; Paulines Publications Africa.

[14] Leung, Y. H., (2003). The politics of decentralization: a case study of school management reform in Hong Kong. In Mok K. H. (Ed.), centralization and decentralization. (pp. 21-38). Hong Kong.
[15] Mbugua Z. K, Komen, Muthaa G. M, Nkonke G. R (2012). Factors Contributing To Students' Poor Performance in Mathematics at Kenya Certificate of Secondary Education in Kenya: A Case of Baringo County, Kenya American International Journal of Contemporary Research Vol. 2 No. 6; 87.

[16] Mutero, J. (2001). Pressure to excel hampering early childhood studies. Daily Nation, August 20, p. 20.

[17] National Research Council and National Academy of Education. (2010). Getting value out of value-added: Report of a workshop. Committee on Value-Added Methodology for Instructional Improvement, Program Evaluation, and Educational Accountability, H. Braun, N. Chudowsky, \& J. Koenig (Eds.). Centre for Education, Division of Behavioural and Social Sciences and Education. Washington, DC: The National Academies Press.

[18] Ogembo, P. O. (2005). Training needs of Heads of Department of Secondary Schools for Effective Curriculum Implementation in Kenya: A case of Eldoret Municipality. Unpublished M. Phil Thesis.

[19] Oyier C. R, Odundo P. A, Obat R. A, Ganira K. L, \& Ochieng J. A. Parental Choice and Learner Achievement in Primary Education in Rachuonyo Sub County, Kenya: Focusing on Quality of Education World Journal of Education. Vol. 5, No. 5: 2015 doi: 10.5430/wje.v5n5p130.

[20] Republic of Kenya (2005), UNESCO/OECD. Early Childhood Policy Review Project\& The Ministry of Education, Science and Technology.

[21] Rutter, M., B. Maugham, P. Mortimer and A. Smith, (1979). Fifteen thousand hours in Secondary schools and their effects on children. Cambridge Harvard University U.S.A.

[22] Springer, Matthew J., John F. Pane, Vi-Nhuan Le, Daniel F. Mc Caffrey, Susan Freeman Burns, Laura S. Hamilton, Brian M. Stecher (2012 b). No Evidence That Incentive Pay for Teacher Teams Improves Student Outcomes: Results from a Randomized Trial. RAND Corporation. Journal of global responsibility, VOL 2, No 2.

[23] Tilbury, D. and Ryan, A. 2011. Today becomes tomorrow: Rethinking business practice, education and learning in the context of sustainability.

[24] Tschanen-Moran, M \& McMaster, P. (2009). Sources of Self Efficacy: Four Professional Development Formats and Their Relationship to Self Efficacy and implementation of a new teaching strategy. The Elementary School Journal, 110 (2). Retrieved http://wmpeople.wm.edu/asset/index/mxtsch/esj4.

[25] UNESCO/OECD (2005) Early Childhood Policy Review Project: The Background Report of Kenya. Ministry of Education, Science and Technology Government of Kenya.

[26] Vaden-Kiernan, N., \& McManus, J. (2005). Parent and family involvement in education: 2002-03 (NCES 2005-043). U.S. Department of Education, National Centre for Education Statistics. Washington, DC: U.S. Government Printing Office. Retrieved $\quad$ Fall 2006 from http://nces.ed.gov/pubs2005/2005043

[27] Voss, T., Kunter, M., \& Baumert, J. (2011). Assessing teacher candidates' general pedagogical/ psychological knowledge: Test construction and validation. Journal of Educational Psychology, 103 (4), 952-969. 
[28] Weihrich, H. and H. Koontz, (1993). Management: A Global Perspective, $10^{\text {th }}$ ed., Mc Graw- Hill, New York, NY.

[29] Wanderi, C. (2008). Failing Management in Kenyan Schools. Nairobi, Kenya.
[30] Yoon, K. S. Duncan T., Lee S. W. Y. Scarloss B, \& Shaplet K. (2007). Reviewing the evidence on how to teach professional development affects student achievement (Issues and answers report REL 2001. No 033) Retrieved from http://www.ies.ed.gov/ncee/edlabs/regions/southwest/pdf/REL 2007033. Pdf. 